\title{
Åland - a peculiar media system
}

\section{Carl-Gustav Lindén}

Department of Information Science and Media Studies, University of Bergen, Norway

\begin{abstract}
This article captures the dynamics of a special case when it comes to media systems, namely the Åland Islands, or Åland, with 6,700 islands and 30,000 inhabitants. Åland is one of three self-governed areas in the Nordic region (the others being the Faroe Islands and Greenland) and is an officially monolingual Swedish-speaking part of Finland, where the majority speak Finnish. In this article, I describe how Åland, despite its small size, has a media system characterised by a diverse and complete offering of local media: two daily newspapers, its own public service and public service offerings from both mainland Finland and neighbouring Sweden, a commercial radio station, and several magazines. However, media diversity is limited by the fact that the same person - a local business tycoon, Anders Wiklöf - controls both newspapers. There is one main research question motivating this study: What are the specific features of the media system in Åland? To be able to answer that, I relied on the analysis of three sets of data: nine interviews, a two-part survey and the media policy adopted in 2018, and transcripts of the preceding political debate.
\end{abstract}

Keywords: Åland, media system, heritage, local media, geography

\section{Introduction}

In this article, I apply the four dimensions of media systems proposed by Hallin and Mancini (2004): structure of the media market, political parallelism, journalistic professionalism, and the role of local government through media policy. Two new dimensions - geography and a sociocultural context -are deemed important and therefore included for understanding the media system, which is based on the idea of a nationstate. Though the literature on media systems is rich, there has been little research on the position of minority-language media within these national systems (Zabaleta et al., 2014a). The examination of generalisable and comparable findings induces a focus on the structural properties and relationships in which "societies were equated with nationstates" (Hamelink, 2014: 41). On the other hand, the nation-state as a unit of analysis lacks transnational features stemming from globalisation of media industries (Esser \& Pfetsch, 2004).

Following Zabaleta and colleagues (2019), this article focuses on media systems as a varied set of news organisations within a community of language and culture and

Lindén, C.-G. (2021). Åland - a peculiar media system. Nordicom Review, 42(S2), 8-21. https:// doi.org/10.2478/nor-2021-0014 
spatially defined. Instead of being a subsystem of the Finnish media system, the locality is considered to be a media system in its own. The study was inspired by research on islands, sometimes called nissology or islandology. Edquist and Holmén (2015) demonstrate that islands, with natural boundaries and sharp edges, offer a particularly good set of samples for exploring the links between geography and the sociocultural context, the relationships of the different groups of people in society and their habits, traditions, and beliefs - in short, a shared identity and sense of history. This study fills a gap, since not much has been written academically about the media system in Åland other than an article on the competition between the two newspapers and their media innovations (Lindén, 2015) and a book chapter on how the newspapers use history and identity to attract an audience (Lindén, 2017). A history was also published of Alandstidningen, Åland's largest and leading news outlet, as an institutional actor both in the local context and with regards to surrounding development (Mattsson-Eklund, 1991).

\section{Geography and the sociocultural context of Åland}

Åland received its status as an autonomous part of Finland in 1921, affirmed by the League of Nations decision known as the Alland Convention. For more than 600 years (from around the twelfth century until 1809), Aland had been part of the Swedish Empire, as had been the whole of what became Finland. After a century under Russian rule (1809-1917), many people would have been happy to reunite with Sweden, and for some years, the islands - due to their strategic position in the Baltic Sea - became a geopolitical pawn. Finland refused to relinquish Åland after the Russian Revolution enabled Finnish independence. The compromise was semi-independence, to protect the Swedish language and local culture. Today, Åland is a territorially-defined area with fixed systems that cement and form linguistic and social structures, sharing similarities with areas in Belgium and Switzerland (McRae et al., 1997). The region has its own legislature, parliament (Lagtinget), and government (Landskapsregeringen), with 16 municipalities, the smallest one having slightly more than 100 inhabitants. The political system is based on multiparty pluralism. In the 2019 local elections, representatives of eight parties were elected to the 30 parliamentary seats; the largest party, with nine seats, is the centrist party, followed by the liberal party. One seat went to a small populist party, Ålands Framtid [the Future of Åland].

Åland's autonomy includes the right to pass laws in areas related to the internal affairs of the region, including media policy, and to exercise its own budgetary power. There is no popular support for full independence, except for Ålands Framtid, who wants "a sovereign, neutral and demilitarized microstate in the ever growing and more and more respected European family of microstates" (Ålands Framtid, 2017).

Only in 1954 did Åland get its own blue, yellow, and red cross flag, followed by stamps in 1984. In 2006, the Internet domain suffix ".ax" was established, offering an opportunity to celebrate identity online, just like the Faroe Islands (".fo") and Greenland (“.gl”). These examples represent concepts of a national symbolic order, the complex set of public symbols that "invoke, transport, and define claims to a shared national identity” (Nieguth \& Raney, 2017: 87).

Alland has branded itself as the Islands of Peace, and pacifism has become second nature to the population (Holmén, 2015). The autonomy of Åland as a peaceful and 
sustainable political solution has also attracted considerable attention from countries facing demands from their minority populations for more influence. Åland has been presented as an example of an arrangement through which a territorial conflict between two states - Finland and Sweden - was solved in a peaceful way (Suksi, 2013), and it has been proposed as a conflict solution model for Iraq (L. Anderson \& Stansfield, 2010) and also as a model in comparison with other European regions (Daftary, 2000; Loughlin \& Daftary, 1999). The heritage objects of Åland have also been compared to heritage-promotion initiatives (imagined heritage) on other islands, such as Shetland and Svalbard (Grydehøj, 2010).

\section{Swedish language as a prime identity marker}

In a survey among decision makers and journalists (Lindén, 2017), the strongest perceived indicator of Ålander identity was the Swedish language (4.7 on a 5-point scale) followed by the autonomy and demilitarisation (4.5 each), the shipping industry (4.4), and the archipelago (4.3). These indicators are far more important than being born on the islands (2.8). Language as key identity indicator is also accentuated in the national anthem, “Ålänningens sång” [“Ålander's song”], adopted in 1922. It ends with the following words: "Loudly shall it sound, our Swedish language/Spoken with an urging voice/Enlighten our path like a sea mark of flames/Show us where we belong/Show us where we belong". In a survey by Bogdan State (2009), respondents rated Swedish language skills as most important, while white skin and Nordic birth were considered to be least important.

While seemingly isolated on an island, the people on Åland - a commercial seafaring micro-nation - are closely connected to both Sweden and the global shipping industry. Immigration has become a key feature of success, as the economic activity, such as the fishing and farming industries, are dependent on low-cost manual labour. Political parties and the media have decided to ensure that immigration is framed as a positive trend. This is an example of externalities of a functioning media system.

\section{Research question, empirical material, and methods}

There is one main research question motivating this study: What are the specific features of the media system in Aland? To be able to answer that, I rely on the analysis of three sets of data:

- interviews with nine different people - the businessperson Anders Wiklöf, three journalists (two female, one male), three politicians (two female, one male), and two local historians (both male) - focused on the media system and the present actors (2014);

- a two-part survey $(N=65)$ with journalists $(N=20$, of which 5 are male), politicians $(N=18$, of which 15 are male), and local decision-makers $(N=27$ of which 22 are male) from the municipalities (2016);

- and the source document of the media policy programme [Mediepolitiskt program] and transcriptions of the political debate that followed after the programme was presented in 2018. 
The empirical aspects of this study consist of semi-structured interviews and surveys focused on local journalists and decision-makers from the region's sixteen municipalities, as well as the local parliament. Interviews were conducted in Swedish and in person in January, July, and December 2014, recorded, and transcribed by a language service provider. Though the interviews were made a few years ago, the media system has remained stable; thus, the results are still considered valid. Texts were broken down according to themes so that data could be compared, conceptualised, and categorised. After that, statements were interpreted and contextualised within broader frames of reference instead of just providing a categorisation (Kvale, 2007). The two surveys with politicians, local decision makers, and journalists $(N=65$; response rate $48 \%$ and gender balance tilting towards a male majority, 41 male respondents versus 24 female) were conducted in May-June 2016. The survey design was informed by findings from the interviews. In the survey, a 5-point Likert scale (strongly agree, somewhat agree, somewhat disagree, strongly disagree, do not know) was used, with most questions being closed-ended and a few opportunities for additional comments. The first two datasets were originally collected for another publication (see Lindén, 2017), and for this particular article, the results presented responded to the particular topic here, the shape and functions of the media system.

This study does not analyse the use of social media, which nevertheless is an important feature of the media system in Aland. When this article was ready for publication, a survey conducted by the local statistics agency ÅSUB showed the increasing importance of social media, and not just among young people ( $\AA$ SUB, 2020). ${ }^{1}$

Having established the aim of the study, the theoretical frame, and the historical, political, and sociocultural context of the study, I now turn to the analysis of the local media system with its population of actors, their interactions, and relation to a wider environment (Nielsen, 2015).

\section{Structure of the media market}

The purpose here is to explore the emergence and characteristics of the media system in Åland, which can be regarded as "institutionally complete" (Moring, 2007) since media is present on all relevant platforms with diverse content. Local media includes two daily newspapers, its own public service and public service offerings from both mainland Finland and neighbouring Sweden, a commercial radio station, and several magazines. Åland is actually the only region in Finland with competition between same-language newspapers, apart from the national evening press (Ilta-Sanomat and Iltalehti). In other regions and cities, such as Vaasa, Turku, or Porvoo, the only competition is between newspapers published in different languages - Swedish and Finnish - or between local public service newsrooms and commercial media.

Åland is a dense media market with around 50 journalists and three major media outlets. In 2019, the legacy newspaper Alandstidningen was published six days a week in print and Sundays online, with 8,312 print and digital subscribers according to its own account (which is slightly down from 8,829 in 2011). As the dominant paper, Alandstidningen is better positioned to attract advertisers, and the newspaper has been one of the most profitable in Finland. The challenger, Nya Aland, was established in 1981 and is published five days a week in print and the remaining two days online. It had around 5,500 subscribers in 2019 (down from 6,683 in 2011). 
The death of print newspapers is yet to be seen in Åland, as they still have a strong base of paying readers. According to a study from 2015, around 14,000 households on the islands $(70 \%)$ were paying to read a printed home-delivered paper in addition to subscribing to papers from Finland or Sweden (Lindén, 2015). Beyond these two newspapers, there is a public service company - Ålands Radio och TV (ÅRTV) founded in 1996 and financed with media fees - as well as a small private radio station, Steel FM.

Audience engagement has become a buzzword among news media during the past few years, and the search for a business model funded by reader revenues. The distance between journalists and their audience has been small, and journalists have been the constant object of attention, including in terms of criticism. As one local (now former) female editor put it in her interview, people are actively seeking interaction:

At some point, I described it as when you go to the grocery store on a Saturday and have to run the gauntlet between the cucumbers and the tomatoes. I am not exaggerating. I cannot go shopping without someone approaching me to talk.

The main reason for the vitality of the media ecosystem is certainly that journalists are attracting paying readers with interesting content. Already from the start, Nya Aland presented itself as at newspaper "owned by readers" with "readers and their needs" in focus (Forsgård, 2006). In Åland, local journalism was never out of fashion; community journalism is here conceptualised by a "nearness to people", in line with recent research (Robinson, 2014). Journalists are blessed with a vital political debate and grassroots engagement in development of local society. The political multiparty system, with the parliament, government, and many municipalities, provides a rich environment for sourcing local news.

\section{Åland's media baron}

The media market structure also raises the importance of media ownership and management, something that Hallin and Mancini did not consider (Lund, 2007). Generally, the minority media in Europe is mostly publicly funded, with privately owned and socially owned media being less common (Zabaleta et al., 2014b). Ownership is a factor that can have an impact on editorial decisions and public interest goals such as media plurality (Doyle, 2002). In the case of Åland, both local newspapers have the same dominant owner, the local business tycoon Anders Wiklöf (who also owns the largest company in the market for groceries, Mathias Eriksson). In the case of Alandstidningen, the owners expect a healthy rate of return on money invested, while the owners of Nya Aland accepted losses for years before the newspaper recently started to make a profit. Anders Wiklöf has been connected to both newspapers for several years. As a businessperson, he has advertised in the local media since April 1970 when he started his first business, a car sales company. About that time, his older brother Lasse Wiklöf began his career as a hard-hitting journalist at Alandstidningen. According to his memoirs, Anders Wiklöf was involved in the first attempt to start a newspaper rival in 1977 (Bruun, 2019), and when it finally happened, he provided financial support to Nya Aland.

In the interview, Anders Wiklöf said he is on a democratic mission: two newspapers contribute to a more vibrant discussion on public affairs - that is, more media means 
more democracy: "I want people in Åland to have the option of two newspapers; they will be able to have their say".

The two papers were fierce competitors for many years, and the underdog Nya Aland was about to overtake Alandstidningen around 2007. Due to countermeasures, however, that did not happen (Lindén, 2015). Wiklöf considered merging the two, but acknowledges that competition between the two papers keeps the cost of advertisements down. Therefore, in addition to the proposed democratic mission, there is also a commercial logic behind using profits from one newspaper as subsidies for the smaller, then-lossmaking, newspaper.

Contrary to the previous "King of Åland", Julius Sundblom, Wiklöf says he has no political ambitions, even though he expresses values close to those espoused by the Social Democrats. At the same time, he airs a certain disdain for the petty side of politics: "Politicians call me on a daily basis and ask me to support this and that. They call me to ask for help, those are the ones tempting me with promises" (quoted in Bruun, 2019: 215). ${ }^{2}$

A local journalist once compared Wiklöf to the Italian media magnate and right-wing populist politician Silvio Berlusconi. Wiklöf responded that in Italy, Berlusconi's face is seen on all television channels: "I asked if someone has seen my face on local television or too often in the newspapers? I asked how often I have called journalists to influence content?" The journalist had to admit that the problem was the other way - it was impossible to reach Wiklöf (Bruun, 2019: 139). In contrast to the Italian media mogul, Wiklöf has not been openly active in politics, and neither can he be blamed for the rise of the right (Statham, 1996), as that part of the political field has very little say on Åland or concern over partisan control of the media and media bias (Durante \& Knight, 2012). However, due to Wiklöf's commercial interests in Åland, one can certainly conclude that there is a certain conflict of interest (Hine, 2001).

\section{Journalistic professionalism}

The non-union association of journalists in Åland has around 50 members, and journalism is highly professionalised with a frequent exchange of reporters from Swedish newsrooms. However, the journalists at the newspapers might have a challenge in balancing their autonomy and professionalism with interests of the owner, and responses to interview questions regarding their relationship with him are vague. Responses range from "Anders Wiklöf is a phenomenon when it comes to newspapers" (female journalist). to "you have to ask Anders about that" (female journalist). Even though known as a stubborn person with strong opinions, Anders Wiklöf said he never intervened in editorial matters: he would not call or send messages to journalists to tell them how to report. Still, he refuses to be a neutral owner and argues strongly against populistic tabloid journalism: "I want them to write positive stuff and an owner has the right to talk about policy," he said in the interview. Intuitively, he might experience what emerges in research - negative news have more influence on consumer sentiments than positive (Hester \& Gibson, 2003), and it makes sense for retailers to prefer primarily positive news. His views also correspond with reader sentiments: international studies show that a majority of news consumers feel that the content offered by news media have the wrong tone (Newman et al., 2019) and some feel that the reporting contains too much "doom 
and gloom", and they prefer to get their updates on what is going on in the world from other sources (Toff \& Nielsen, 2018).

Media scholars within the field of political economy tend to believe that businesses use all means, such as advertising, to assert control over news directly and through self-censorship (Craig, 2004; Croteau \& Hoynes, 2001). In this specific case, the line between news and business might be more imaginary or porous than journalists or the owner want to admit, although not subject to the most blatant forms of special treatment or self-censorship. However, research goes against the idea of Nordic editors and journalists systematically serving owners and business managers (Lund, 2007).

Wiklöf elaborates on the importance of quality journalism:

Every society needs someone who scrutinises power critically. It has to be journalists who do the job [...] or someone else if they are not able to handle that mission. If no one keeps a close check on those with power, it ends badly. It ends in corruption, a society that functions worse with more poverty and enormous differences in income. (quoted in Bruun, 2019: 269)

Wiklöf defends his dominance over media: "Sometimes people challenge my role and say my influence as a large owner in both newspapers is too big. That is rubbish" (quoted in Bruun, 2019: 138). As an owner, Wiklöf intervened when the former management of Nya Aland wanted to terminate the print edition and go online only, against active opposition from readers. Wiklöf saw the problem from the perspective of both owner and advertiser - online advertising provides no revenue. Instead, the newspaper was forced to get rid of all activities that did not bring in revenue, such as web-TV. Now the newspaper is free from debt and makes a small profit, focusing on both the societal and economic value of local journalism: "The two newspapers are doing well, because they focus on news that concerns Åland. That is their niche; you can get world news elsewhere" (quoted in Bruun, 2019: 140).

This part of the study illustrated the struggle journalists have to go through to maintain their professional independence, but with a strong dominant owner, they need to sometimes take into account his opinions.

\section{Political and economic parallelism}

The links between media, business, and politics have traditionally been strong in Åland. For more than four decades, the political field was controlled by the founder of Alandstidningen, Julius Sundblom, and his followers, later called old-sundblomians. He detested political parties and instead believed that the most important path was to stand united behind the nation's autonomy and defend it (Lindh, 1984). Only after his death in 1945 were parties gradually established. In the 1960s, modern Åland began to take shape with a new parliamentary system, the emergence of a modern and professional bureaucracy, and its own seat on the Nordic Council (Lindén, 2017). However, following Anderson (2006), we could consider the emergence of newspapers (print capitalism) - in this case Alandstidningen, established in 1891 - as one of the strongest sources of Åland's nationalism. People on the islands are reminded of that at least once a year; every 9 June, an official day of autonomy, is celebrated around the statue of Julius Sundblom in a park in the only city, Mariehamn, with flowers, music, and marches. 
This celebration serves as a symbolic representation of the nation in the context of state ceremonies and public rituals (McCrone \& McPherson, 2009). The editor-in-chief of Alandstidningen is expected to participate in the celebrations, as well as members of the local parliament. Jan Helin, when editor-in-chief, described the founder in his speech as someone who leveraged enormous influence through his newspaper monopoly:

In political action, Julius Sundblom was more interested in results than in amiable democratic principles. During one period, he was chairman in the parliament, editor-in-chief for Ålandstidningen and chairman of the Board of Trustees for Bank of Åland [translated]". (Helin, 2005)

Discontented journalists at Alandstidningen founded Nya Aland as a cooperative in 1981 (Forsgård, 2006; Mattsson-Eklund, 1991) and catered to readers who were not happy with the dominance of political and economic elites. This new venture immediately divided the population in two: those inclined to Gamlan - the old one, or blue one (the colour most frequently used in design and marketing), considered more conservative and friendly to the establishment - and those inclined to Nyan - the new one, or red one, seen as more radical, feminist, and left-leaning (Lindén, 2015). The historian Janne Holmén exemplifies how the establishment of Nya Aland opened up a debate on history, culture, and identity with alternative interpretations and accounts that until then had been suppressed: "the society on Åland started to become less monolithic in the 1980s, and this was reflected in the history writing" (2015: 157). Holmén notes that previous history writing had been commissioned for a specific mission: to create a grand vision of the past. In this sense, the new newspaper helped the community break free of institutionalised truths.

This also points to the normative argument that having newspapers of different political colour is good for democracy and public debate (Napoli, 2009), a view which is also shared by Ålandic politicians in interviews for this article. However, a female social democrat stated that newspapers are also using filters to present their own views, thus becoming actors with their own agency: "For us who are dependent on media to get our message out, this diversity vitalises the debate, even though it is quite easy to predict how the two newspapers react to things".

As a small society with short distances between actors, journalistic autonomy is not easy to uphold: "You have no problem getting through in the newspapers since they can write about almost anything actually, but [there is no] deep and investigative journalism: I can feel that there is no scrutiny at times." One reason, says a female politician from the liberal party, is that the distance between journalists and the people they write about is very short, so even if politicians voice strange views, they are polished: "There is an interdependence between journalists and politicians".

Comparing the two newspapers, there is a certain division of political and historical differences. The survey revealed a general agreement among politicians and local decision-makers that Alandstidningen to a larger extent uses tradition, history, and identity as a political tool (4.5 on a 5-point scale) and to find support for its own views (4.2) compared with Nya Aland (3.8 for political tool; 3.7 for own views). The respondents agree that Alandstidningen wants to stand for an official and politically correct view of history (4.5). This view is reflected in some of the interview responses, where one of the female politicians from the Social Democratic Party notes: "Alandstidningen is 
more, kind of Sundblomian perhaps, more micro-nationalistic and isolationist, while Nya Aland is part of a larger context where compromises and contacts are the road ahead".

A female journalist points in her interview to the long tradition of supporting a particular historical view compared with an alternative chronicle of local development: Alandstidningen stands for continuity and heritage after Julius Sundblom, and Nya Aland "is the underdog that is often in opposition to the older newspaper". A female politician from the Social Democratic Party confirms that the self-reported history of Alandstidningen is organically closely related to the development of autonomy: "Alandstidningen has been the strongest political actor for independence, more powerful than both governments and parliaments or individual politicians". Additionally, a former female journalist says the media system has a binary character that becomes obvious when looking at the opinion pages, which are "two different mental systems" without any real exchange of opinions. Thus, we can conclude that two newspapers also provide platforms for polarisation.

The survey shows stronger support for the view that Nya Aland is important for democracy, especially among members of the local parliament (4.8 on a 5-point scale), but less so among local decision-makers (4.0). One would thus suspect that it would be a loss for local democracy if Nya Aland disappeared, and this opinion is shared by members of the local parliament. What would happen? Would it limit the space for different opinions and a diverse public debate? A male politician from the centrist party said in the interview that two newspapers make the debate richer and contribute to building a more just society: "It would be an enormous loss to Åland and our public debate if the newspaper [Ny A Aland] disappeared and I think this is true despite what you think about it [the newspaper]". A male journalist noted in the survey that public debate benefits from two different platforms for opinion, since "there is room for more than one direction. If one newspaper does not care, the other probably will. This has intrinsic value".

Finally, in addition to political parallelism, we also must take into account the economic bindings. In recent years, the editor-in-chief of Nya Aland left and took an active role in the Social Democratic Party. However, her rival at Alandstidningen did not enter political life, but left journalism to manage Wiklöf's company for groceries, Mathias Eriksson, and was replaced by a former business lobbyist. Thus, focusing on political parallelism will not capture the full story of media systems, since economic parallelism can be just as powerful.

\section{"What if?" scenario}

The survey results from 2016 show that local decision-makers are less concerned with what would happen if Nya Aland disappears, because they feel that public service radio is more important for the local debate. Herein lies a reason for caution, since the non-response rate of local decision-makers on some questions regarding the media was as much as 32 per cent. The plausible reason for this is that Nya Aland is not widely read in the lesser populated areas (Lindén, 2015). This is also reflected in survey comments such as "I read Alandstidningen every day, seldom Nya Aland" or "I don't subscribe to Nya Aland". Shown in the survey, some respondents actually thought the cost of two newspapers is too high. A local male decision-maker stated that "the society on Åland is so small and limited, otherwise also transparent, that there is no need for 
two newspapers". He thinks they could fold into one newspaper with two "differently coloured opinion pages" because of "the high costs to society". Similar views came from another male local decision-maker who suggested that media diversity is an illusion: "In practice, there is no big difference - even if the public debate sometimes implies there is one".

\section{Media policy}

In this section, we look at the role of local government in Aland and its media policy with a specific focus on public service media. We have established that Åland has a strong commercial news sector that allows for some media diversity, but public service media's contributions to democracy and community integration are well established (McLeod et al., 1996; Shah et al., 2017). Less known are the specific policies that make these contributions possible, but according to Benson and colleagues (2017), professional autonomy and civic accountability in public media are supported by 1) funding established for multi-year periods; 2) legal charters that restrict partisan government influence; 3) oversight agencies, with arm's length independence from the government in power; and 4) audience councils. The media policy in Åland, adopted by the local government in 2018 , seems based on these principles. It states that access to verified information is a cornerstone of society, and the aim is to map what interventions are necessary to promote a reliable and diverse supply of media content - both local production and content from Sweden (Ålands Landskapsregering, 2018). The policy interestingly underlines that public service should "contribute to increased insights and understanding of the foundational principles of the autonomy and preserving Åland's Swedish language and culture" (Ålands Landskapsregering, 2018: 11). So how is public service defined? Looking at the Public Service Handbook (ÅRTV, 2019: 22), a spatially expansive view of what the service should include is provided: "We will pay attention to events around the whole of Åland but also to things in other parts of the world that affect us and Ålanders [...] around the world". This statement could almost be the policy of some diasporic media (see, e.g., Georgiou, 2005).

Some tangible effects of the new policy could soon be observed. In autumn 2019, the parliament decided to transition from public-service funding by licenses to a media fee of EUR 100 per year. In addition, ÅRT is overseen by a board consisting of experts not politicians - thus adhering to the arm's length principle.

In preparation for the new media policy, the ruling parties declared that an independent "public service is an important part of the autonomy and the democratic system [and] important in a small society" with a mission to "serve the public with information, knowledge and culture" (Sjögren \& Gunell, 2015: 15). This declaration is in line with other mission statements in the Nordic region, where public service combined with commercial news media is an integral part of the welfare state concept (Syvertsen et al., 2014). However, Finland is the only Nordic country in which the government does not provide any direct subsidies for the press, which applies to Åland as well.

Another important feature in the media policy is access to media content from neighbouring Sweden, especially produced by the public service provider SVT. In the digital age, copyright issues hinder access to all online content on the SVT web player. When content is geo-blocked because of copyright issues - for instance, sports events for which 
access is defined in national agreements - it sometimes means that viewers in Åland are trapped between two nations, not able to watch any real-time content.

In preparation for the policy document, the commercial media actors reflected the discourse followed by commercial media in the Nordic countries: they recommended that public service should be restricted to areas where there is no commercial potential. Neither was the response from ÅRTV surprising: "we are present on all platforms where the audience is" and public service media has become "more important" than ever. When the programme was presented by the responsible minister, Mika Nordberg, he noted that people in Åland are "spoiled" when it comes to media diversity, but he underlined that public service, despite that, remains important (Nordberg, 2018).

\section{Discussion}

There is one main research question motivating this study: What are the specific features of the media system in Åland? To answer that question, three sets of data were collected: a series of semi-structured interviews with nine people - the businessperson Anders Wiklöf, three journalists, three politicians, and two amateur historians (2014); a two-part survey with journalists, politicians, and local decision-makers from the municipalities (2016); and the source document of the media policy programme and transcriptions of the political debate that followed after the programme was presented in 2018.

Åland is an example of a region which bears some similarities to other minority areas in Europe, having access to the same-language media as those on the other side of the border - in this case, neighbouring Sweden. Access to Swedish media is one of the core issues, since media supply in Swedish language is limited in Finland. The diversity of the media system in Åland is broad, with local politicians admitting they feel "spoiled" with two economically successful newspapers combined with their own public service media and public service offerings from both Finland and Sweden. Still, it is not possible to neglect the importance of one benevolent business patron for the health of the media system, upholding the newspaper duopoly, and enabling a diversity of opinion. Local policy-makers must reflect on a future without the individual that safeguards the present media situation, Anders Wiklöf. Thus, the existing media diversity is dependent on the goodwill and personal preferences of Anders Wiklöf, which is not acknowledged in the media policy. The study could provide some interesting reading for decision-makers trying to come up with media policies aimed at creating greater diversity of opinion and ideas in their communities.

One theoretical contribution of this article is the inclusion of two new dimensions - geographical and sociocultural context - that are deemed important for understanding the media system. Most accounts of media systems depart from the idea of a nation-state. The media has been an important part of societal development in Åland, and one of the first markers of identity was the inception of the newspaper Alandstidningen in 1891. Historically, this newspaper has been one of the most important drivers behind societal development in this autonomous region. The legacy newspaper Alandstidningen is an actor unto itself when it comes to defining what it means to be from Åland and how society should be constructed and negotiated. Its rival Nya Aland provides alternative views. Together, they offer two separate platforms for open public debate; however, it is not clear that the normative ideals of media diversity and a plurality of 
opinion (Napoli, 2009) is shared by everyone, at least not all local decision-makers outside the only city in Åland, Mariehamn. Finally, this case study shows how legacy newspapers continue to play an important role in their local communities and points to different ways in which they engage their readers. The study also shows that there is room for differentiation in editorial strategies, despite the small size of the community and institutionalised truths about heritage, history, and identity. Most prominently, the newspaper Nya Aland actually managed to create a situation in which Åland could break free from its past.

\section{Funding}

Work on this article has been funded by Ålands Kulturstiftelse (The Cultural Foundation of Åland) and The Society of Swedish Literature in Finland (SLS).

\section{Notes}

1. The survey shows that television is the most important source of information for everyone (78\%), followed by social media (72\%), and newspapers as number three (71\%). The single most important news source was Alandstidningen ( $70 \%$ daily or almost daily use). Young people are of course using social media more; $89 \%$ of people $13-24$ years old (77\% daily use of Snapchat and $42 \%$ of Tiktok).

2. All quotes taken from Bruun (2019), a biography of Wiklöf, have been translated to English by the author.

\section{References}

Anderson, B. (2006). Imagined communities: Reflections on the origin and spread of nationalism (Rev. ed.). London: Verso.

Anderson, L., \& Stansfield, G. (2010). Avoiding ethnic conflict in Iraq: Some lessons from the Åland Islands. Ethnopolitics, 9(2), 219-238. https://doi.org/10.1080/17449051003784770

Benson, R., Powers, M., \& Neff, T. (2017). Public media autonomy and accountability: Best and worst policy practices in 12 leading democracies. International Journal of Communication, 11, 1-22. https://ijoc.org/ index.php/ijoc/article/view/4779

Bruun, S. (2019). Anders Wiklöf: Murarens son [Anders Wiklöf: The son of a bricklayer]. Helsinki: Schildts \& Söderströms.

Craig, R. L. (2004). Business, advertising, and the social control of news. Journal of Communication Inquiry, 28(3), 233-252. https://doi.org/10.1177/0196859904264686

Croteau, D., \& Hoynes, W. (2001). The business of media: Corporate media and the public interest. Thousand Oaks, California: Pine Forge.

Daftary, F. (2000). Insular autonomy: A framework for conflict settlement? A comparative study of Corsica and the Aland Islands. Flensburg, Germany: European Centre for Minority Issues.

Doyle, G. (2002). Media ownership: The economics and politics of convergence and concentration in the UK and European media. Los Angeles: Sage. http://dx.doi.org/10.4135/9781446219942

Durante, R., \& Knight, B. (2012). Partisan control, media bias, and viewer responses: Evidence from Berlusconi's Italy. Journal of the European Economic Association, 10(3), 451-481. https://doi.org/10.1111/ j.1542-4774.2011.01060.x

Edquist, S., \& Holmén, J. (2015). Islands of identity: History-writing and identity formation in five island regions in the Baltic Sea. Stockholm: Södertörn University.

Esser, F., \& Pfetsch, B. (2004). Meeting the challenges of global communication and political integration: The significance of comparative research in a changing world. In F. Esser, \& B. Pfetsch (Eds.), Comparing political communication: Theories, cases, and challenges (pp. 384-410). New York: Cambridge University Press.

Forsgård, H. (2006). Nya Åland 25 år [Nya Åland 25 years]. Mariehamn, Åland Islands: Nya Åland.

Georgiou, M. (2005). Diasporic media across Europe: Multicultural societies and the UniversalismParticularism continuum. Journal of Ethnic and Migration Studies, 31(3), 481-498. https://doi. org/10.1080/13691830500058794

Grydehøj, A. (2010). Uninherited heritage: Tradition and heritage production in Shetland, Åland and Svalbard. International Journal of Heritage Studies, 16(1-2), 77-89. https://doi.org/10.1080/13527250903441796

Hallin, D. C., \& Mancini, P. (2004). Comparing media systems: Three models of media and politics. Cambridge: Cambridge University Press. https://doi.org/10.1017/CBO9780511790867 
Hamelink, C. J. (2014). Global communication. London: Sage.

Helin, J. (2005). Jan Helins anteckningar: Vårt åländska kulturarv [Jan Helin's notes: Our Aland cultural heritage]. Ålands framtid. https://alandsframtid.ax/arkiv/4424

Hester, J. B., \& Gibson, R. (2003). The economy and second-level agenda setting: A time-series analysis of economic news and public opinion about the economy. Journalism \& Mass Communication Quarterly, 80(1), 73-90. https://doi.org/10.1177/107769900308000106

Hine, D. (2001). Silvio Berlusconi, the media and the conflict of interest issue. Italian Politics, 17, 261-275. https://www.jstor.org/stable/43041922

Holmén, J. (2015). Åland - navigating between possible identities, 1852-2012. In S. Edquist, \& J. Holmén (Eds.), Islands of identity: History-writing and identity formation in five island regions in the Baltic Sea (pp. 143-241). Stockholm: Södertörn University.

Kvale, S. (2007). Doing interviews. Los Angeles: Sage.

Lindén, C.-G. (2015). Media innovation in a strange place: Newspaper differentiation on Åland. The Journal of Media Innovations, 2(2), 40-57. https://doi.org/10.5617/jmi.v2i2.993

Lindén, C.-G. (2017). Media building community: Audience engagement in a micro-nation. In L. W. Císařová (Ed.), Voice of the locality: Local media and local audience (pp. 133-154). Brno, Czech Republic: Masaryk University Press.

Lindh, K. (1984). Det åländska samhället [Åland society]. Esbo, Finland: Ab Svenska Läromedel.

Loughlin, J., \& Daftary, F. (1999). Insular regions and European integration: Corsica and the Aland islands compared. Flensburg, Germany: ECMI-European Centre for Minority Issues.

Lund, A. B. (2007). Media markets in Scandinavia: Political economy aspects of convergence and divergence. Nordicom Review, (Jubilee Issue), 121-134.

Mattsson-Eklund, B. (1991). 100 år med Åland [100 years with Åland]. Mariehamn, Åland Islands: Tidningen Åland.

McCrone, D., \& McPherson, G. (2009). National days: Constructing and mobilising national identity. New York: Springer.

McLeod, J. M., Daily, K., Guo, Z., Eveland, W. P., Bayer, J., Yang, S., \& Wang, H. (1996). Community integration, local media use, and democratic processes. Communication Research, 23(2), 179-209. https:// doi.org/10.1177/009365096023002002

McRae, K. D., Helander, M., \& Luoma, S. (1997). Conflict and compromise in multilingual societies, Vol. 3: Finland. Waterloo, Ontario: Wilfrid Laurier University Press.

Moring, T. (2007). Functional completeness in minority language media. In M. Cormack, \& N. Hourigan (Eds.), Minority language media: Concepts, critiques and case studies (pp. 17-33).

Napoli, P. M. (2009). Media diversity and localism: Meaning and metrics. Mahwah, New Jersey: Lawrence Erlbaum Associates.

Newman, N., Fletcher, R., Kaloqeropoulos, A., \& Nielsen, R. K. (2019). Reuters Institute digital news report 2019. Oxford: Reuters Institute for the Study of Journalism, University of Oxford. https://reutersinstitute. politics.ox.ac.uk/sites/default/files/2019-06/DNR_2019_FINAL_0.pdf

Nieguth, T., \& Raney, T. (2017). Nation-building and Canada's national symbolic order, 1993-2015. Nations and Nationalism, 23(1), 87-108. https://doi.org/10.1111/nana.12170

Nielsen, R. K. (2015). Local journalism: The decline of newspapers and the rise of digital media. New York: IB Tauris.

Nordberg, M. (2018). Mediepolitiskt program [Media Policy Programme]. https://www.lagtinget.ax/arenden/ mediepolitiskt-program-14762/42603

Robinson, S. (2014). Introduction: Community journalism midst media revolution. Journalism Practice, 8(2), 113-120. https://doi.org/10.1080/17512786.2013.859822

Shah, D. V., McLeod, D. M., Rojas, H., Cho, J., Wagner, M. W., \& Friedland, L. A. (2017). Revising the communication mediation model for a new political communication ecology. Human Communication Research, 43(4), 491-504. https://doi.org/10.1111/hcre.12115

Sjögren, K., \& Gunell, C. (2015). Regeringsprogram för ett hållbart Åland - kraftsamling för stabilitet och förändring [Government programme for a sustainable Åland - demonstration of strength for stability and change]. Mariehamn, Åland Islands: Ålands Landskapsregering. https://www.regeringen.ax/sites/www. regeringen.ax/files/attachments/guidedocument/regeringsprogram-for-ett-hallbart-aland.pdf

State, B. (2009). Strangers by desire: Attitudes toward immigrants in the Aland islands. Mariehamn, Åland Islands: Åland Islands Peace Institute.

Statham, P. (1996). Berlusconi, the media, and the new right in Italy. The International Journal of Press/ Politics, 1(1), 87-105. https://doi.org/10.1177/1081180X96001001007

Suksi, M. (2013). Territorial autonomy: The Åland islands in comparison with other sub-state entities. In K. Zoltán (Ed.), Autonomies in Europe: Solutions and Challenges (pp. 37-58). Budapest: L'Harmattan. 
Syvertsen, T., Mjøs, O. J., Enli, G. S., \& Moe, H. (2014). The media welfare state: Nordic media in the digital era. Ann Arbor, Michigan: University of Michigan Press. https:/www.doi.org/10.3998/ nmw.12367206.0001.001

Toff, B., \& Nielsen, R. K. (2018). "I just google it": Folk theories of distributed discovery. Journal of Communication, 68(3), 636-657. https://doi.org/10.1093/joc/jqy009

Zabaleta, I., Ferré-Pavia, C., Gutierrez, A., Fernandez, I., \& Xamardo, N. (2014a). European minority language media and journalism: Framing their marginal reality. International Communication Gazette, 76(3), 275-295. https://doi.org/10.1177/1748048513516907

Zabaleta, I., Ferré-Pavia, C., Gutierrez, A., Fernandez, I., \& Xamardo, N. (2014b). Future business innovation in minority language media: Back to basics. Journalism Practice, 8(5), 508-518. https://doi.org/10.10 80/17512786.2014.895518

Zabaleta, I., Gutierrez, A., Ferré-Pavia, C., Fernandez, I., \& Xamardo, N. (2019). Facts and transformations in European minority language media systems amid digitalization and economic crisis. International Communication Gazette, 81(3), 235-258. https://doi.org/10.1177/1748048518754749

Ålands Framtid. (2017). A brief summary of Alands framtid. https://alandsframtid.ax/en

Ålands Landskapsregering. (2018). Mediepolitiskt program [Media Policy Programme]. Mariehamn, Åland Islands: Ålands Landskapsregering. https://www.lagtinget.ax/dokument/meddelande-52017-2018-11191

ÅRTV. (2019). Public service-handbok [Public service handbook]. Mariehamn: ÅRTV. https://alandsradio. ax/sites/default/files/page/fc-list-doc/public_service-handbok_vuxna_-_slutlig_version_0.pdf

ÅSUB (2020). Media use on Åland 2020. Mariehamn: ÅSUB https://www.asub.ax/sv/utredning/medievanor-pa-aland-2020

(C) 2021 Nordicom and respective authors. This is an Open Access work licensed under the terms of the Creative Commons Attribution-NonCommercial-NoDerivatives 4.0 International Public licence (CC BY-NC-ND 4.0). To view a copy of the licence, visit https://creativecommons.org/ licenses/by-nc-nd/4.0/ 